resolution and prevent serious sequelae. ${ }^{13,14}$ The EPOS 2012 guidelines have stricter recommendations and stratify treatment based on case categorisation;

1) common cold/acute viral rhinosinusitis

2) acute post-viral rhinosinusitis (moderate symptoms recommend intranasal steroids but no antibiotics), and

3) acute bacterial rhinosinusitis (severe symptoms - antibiotics and intranasal steroids recommended). ${ }^{2}$

For antibiotic rates to decrease, we need to continue to educate medical providers. In addition, there must be changes in societal expectations, since patient demand is a strong barrier to limiting prescription rates. Subjects in this study by Stjärne and colleagues reported poor QoL. ${ }^{6}$ They noted high rates of pain/discomfort and limitation to usual activities, so understandably they desired symptom relief. But antibiotics are not always beneficial and can cause harm. Physicians should be aided by national programmes to educate both healthcare providers and the general population. ${ }^{15}$

This is a timely message. The American Academy of Allergy, Asthma, and Immunology has recently updated its teaching slides on both acute and chronic rhinosinusitis. This was an international effort involving experts from around the world from the fields of allergy and immunology, otolaryngology, and radiology. These new teaching slides provide a review of the epidemiology, diagnosis and management of rhinosinusitis, and can be accessed without charge at: http://education.aaaai.org/courses. Additional teaching slides are available on a wide variety of respiratory conditions, providing Continuing Medical Education (CME) credits for trainees, primary care physicians and specialists.

Conflicts of interest The author declares speaker's honoraria for Teva and Sunovion.

Commissioned article; not externally peer-reviewed; accepted 10th May 2012; online 17th May 2012

(c) 2012 Primary Care Respiratory Society UK. All rights reserved http://dx.doi.org/10.4104/pcrj.2012.00045

Prim Care Respir J 2012:21(2):130-1

\section{References}

1. Friedlander SL, Larkin EK, Rosen CL, Palermo TM, Redline S. Decreased quality of life associated with obesity in school-aged children. Arch Pediatr Adolesc Med 2003;157(12):1206-11. http://dx.doi.org/10.1001/archpedi.157.12.1206

2. Fokkens WJ, Lund V, Mullol J, et al. The european position paper on rhinosinusitis and nasal polyps 2012. Rhinology - Supplement 2012;23:1-299

3. Cherry DK, Woodwell DA, Rechtsteiner EA. National ambulatory medical care survey: 2005 summary. Adv Data 2007;387:1-39.

4. Wang DY, Wardani RS, Singh $\mathrm{K}$, et al. A survey on the management of acute rhinosinusitis among asian physicians. Rhinology 2011;49(3):264-71.

5. Meltzer EO, Hamilos DL, Hadley JA, et al. Rhinosinusitis: Establishing definitions for clinical research and patient care. J Allergy Clin Immunol 2004;114(6 Suppl):155-212 http://dx.doi.org/10.1016/j.jaci.2004.09.029

6. Stjarne P, Odeback P, Stallberg B, Lundberg J, Olsson P. High costs and burden of illness in acute rhinosinusitis: Real-life treatment patterns and outcomes in swedish primary care. Prim Care Respir J 2012;21(2):174-9 http://dx.doi.org/10.4104/ pcrj.2012.00011

7. Schatz M, Zeiger RS, Chen W, Yang SJ, Corrao MA, Quinn VP. The burden of rhinitis in a managed care organization. Ann Allergy Asthma Immunol 2008;101(3):240-7. http://dx.doi.org/10.1016/\$1081-1206(10)60488-7

8. Vlastos I, Athanasopoulos I, Mastronikolis NS, et al. Impaired mucociliary clearance in allergic rhinitis patients is related to a predisposition to rhinosinusitis. Ear Nose Throat J 2009:88(4):E17-9.

9. Ciprandi G, Buscaglia S, Pesce G, Villaggio B, Bagnasco M, Canonica GW. Allergic subjects express intercellular adhesion molecule--1 (ICAM-1 or CD54) on epithelia cells of conjunctiva after allergen challenge. J Allergy Clin Immunol 1993;91(3):78392. http://dx.doi.org/10.1016/0091-6749(93)90198-0

10. Hartmann E, Graefe H, Hopert A, et al. Analysis of plasmacytoid and myeloid dendritic cells in nasal epithelium. Clin Vaccine Immunol 2006;13(11):1278-86. http://dx.doi.org/10.1128/CVI.00172-06

11. Venekamp RP, Rovers MM, Verheij TJ, Bonten MJ, Sachs AP. Treatment of acute rhinosinusitis: Discrepancy between guideline recommendations and clinical practice. Fam Pract 2012 (Epub ahead of print). http://dx.doi.org/10.1093/fampra/cms022

12. Gwaltney JM,Jr, Wiesinger BA, Patrie JT. Acute community-acquired bacterial sinusitis: The value of antimicrobial treatment and the natural history. Clin Infect Dis 2004;38(2):227-33. http://dx.doi.org/10.1086/380641

13. Chow AW, Benninger MS, Brook I, et al. IDSA clinical practice guideline for acute bacterial rhinosinusitis in children and adults. Clin Infect Dis 2012;54(8):e72-e112. http://dx.doi.org/10.1093/cid/cis370

14. Rosenfeld RM. Clinical practice guideline on adult sinusitis. Otolaryngol Head Neck Surg 2007;137(3):365-77. http://dx.doi.org/10.1016/j.otohns.2007.07.021

15. Molstad S, Erntell M, Hanberger $\mathrm{H}$, et al. Sustained reduction of antibiotic use and low bacterial resistance: 10-year follow-up of the swedish strama programme. Lancet Infect Dis 2008;8(2):125-32. http://dx.doi.org/10.1016/S1473-3099(08)70017-3

\title{
Obesity, airflow limitation, and respiratory symptoms: does it take three to tango?
}

\section{See linked article by Zutler et al. on pg 194}

\section{*Frits ME Franssen ${ }^{\mathrm{a}}$ \\ a Program Development Center, $\mathrm{CIRO}+$, Center of Expertise for Chronic Organ Failure, Horn, The Netherlands}

*Correspondence: Dr Frits ME Franssen, CIRO+, Center of Expertise for Chronic Organ Failure, PO Box 4080, 6080 AB Haelen, The Netherlands

Tel: +31-475-587600 Fax: +31-475-587592

E-mail: fritsfranssen@ciro-horn.nl
Respiratory symptoms such as dyspnoea and chronic cough are common in the general population ${ }^{1}$ and are associated with reduced health status even in people without any disease of the airways. ${ }^{2}$ The presence of objective lung function impairment or bronchial hyperresponsiveness does not alter this association, ${ }^{2}$ indicating that other factors contribute to dyspnoea and chronic cough in the general population. Unravelling these factors remains a relevant challenge and a prerequisite to prevention and treatment of respiratory symptoms. One of the factors which probably contributes to the presence of respiratory symptoms is obesity, defined as a body mass index (BMI) of $\geq 30 \mathrm{~kg} / \mathrm{m}^{2}$.

The increasing prevalence of obesity is one of the major global 
public health problems of the current decade. It is projected that this obesity epidemic will escalate even further, especially as a result of a dramatic rise in obesity in low- and middle-income countries. ${ }^{3}$ In 2008, an estimated 500 million adults around the world were obese. ${ }^{4}$ Obesity substantially raises the risk of morbidity and mortality. It is related to the development of cardiovascular risk factors such as reduced $H D L$, non-insulin dependent diabetes mellitus and hypertension, ${ }^{5}$ and to the incidence of cardiovascular events. ${ }^{6}$ In addition, obesity is a major risk factor for gallbladder disease, osteoarthritis, accidents, and certain types of cancer. In 2009, the World Health Organization (WHO) estimated that obesity was the fifth leading risk factor for death, accounting for nearly 3 million deaths per year.

A link between obesity and the respiratory system is well established. Obesity affects pulmonary function at rest, with a reduction in functional residual capacity $(\mathrm{FRC})^{7}$ as its most prominent effect. However, the effects of obesity on airway function are limited. Forced expiratory volume in one second $\left(\mathrm{FEV}_{1}\right)$ and forced vital capacity (FVC) are usually preserved, ${ }^{8}$ and so the $\mathrm{FEV}_{1} / \mathrm{FVC}$ ratio often remains normal. However, obese subjects are at increased risk of expiratory flow limitation as a result of their breathing at lower lung volume, ${ }^{7}$ and small airways airflow obstruction may be present. Diffusing lung capacity of carbon monoxide (DLCO) is also in the normal range or increased in obesity. ${ }^{9}$ Obese subjects free of respiratory disease report decreased ability to perform daily physical activities due to increased breathlessness in comparison with healthy age- and gender-matched normal weight subjects. ${ }^{10}$ In addition, breathing discomfort is significantly higher at any given submaximal cycle work rate in obese subjects. ${ }^{10}$

In addition to the 'physiologic' effects of excess body fat mass on the lungs, obesity is increasingly linked to chronic respiratory conditions. Obesity predisposes to obstructive sleep apnoea, ${ }^{11}$ pulmonary embolism, ${ }^{12}$ and asthma. ${ }^{12}$ Furthermore, obesity probably contributes to heterogeneity in pulmonary and systemic manifestations in patients with chronic obstructive pulmonary disease (COPD). ${ }^{13}$ Like obesity, COPD is a major cause of worldwide morbidity and mortality, and the burden of COPD will increase over the next few decades. The degree of airflow limitation in COPD is a poor predictor of patient-related outcomes including dyspnoea, cough, exercise tolerance and health status. ${ }^{14}$ Therefore, it is important to understand the impact of concomitant conditions, including obesity, on relevant outcomes in COPD. While it was recently reported that obese COPD patients have increased dyspnoea at rest and poorer health status compared to normal weight patients, ${ }^{14}$ some favourable effects of obesity in COPD have been described. Obesity results in a reduction of static lung hyperinflation in COPD, irrespective of the severity of disease. ${ }^{15}$ Also, peak cycling capacity is preserved in obese COPD patients compared to non-obese patients with a comparable degree of airflow limitation, ${ }^{15}$ although the distance covered during a 6minute walk test (6MWT) is reduced. ${ }^{16}$ M oreover, dyspnoea ratings are consistently lower during cycling in obese patients, probably due to the beneficial effects of the excessive fat mass on dynamic ventilatory mechanics. ${ }^{15}$ Finally, in patients with severe COPD, obesity is associated with improved survival, ${ }^{17}$ while its contribution to the increased cardiovascular morbidity and mortality in less advanced disease remains to be established. ${ }^{18}$

Since the worldwide prevalence of both chronic airflow obstruction as well as obesity is increasing, and a large proportion of people with respiratory symptoms are currently undiagnosed and untreated, ${ }^{2}$ unravelling the combined effects of these conditions is a major healthcare priority. The study by Zutler et al. ${ }^{19}$ in this issue of the PCRJ greatly enhances our understanding of the complex interactions between obesity, airflow obstruction and respiratory symptoms, and performance. In a cohort of 371 middle-aged subjects without an ICD9-CM diagnosis of COPD, respiratory symptoms including productive cough and exercise-induced dyspnoea were evaluated. Clinical assessment included pre-bronchodilator spirometry, and measurement of BMI, 6MWT, and lower extremity function. The frequencies of airflow obstruction ( $\left.\mathrm{FEV}_{1} / \mathrm{FVC}<0.70\right)$ and obesity were nearly $19 \%$ and $40 \%$, respectively. Obese subjects were much less likely to have airflow limitation. Remarkably, not airflow limitation but obesity, was associated with increased respiratory symptoms, poor self-reported health and decreased functional performance.

The findings of this study are clinically relevant to healthcare professionals confronted with globally expanding populations of patients with dyspnoea, obesity, chronic airflow limitation or any combination of these. The study suggests that strategies aimed at improving respiratory symptoms and enhancing performance in obese patients per se in the general population might need to focus on weight reduction rather than on diagnosing and treating airflow limitation. Whether strategies aimed at reducing obesity are indeed effective, and what amount of weight loss would result in clinically important improvements in these outcomes, needs further investigation. Furthermore, it is not clear whether more severe impairment in lung function than was present in this study ${ }^{19}$ (median $\mathrm{FEV}_{1}$ was $83 \%$ of predicted) would outweigh the impact of obesity on respiratory symptoms and functional capacity in a general population. Finally, it is currently unknown whether subjects with concomitant obesity and COPD would clinically benefit from weight reduction, since obesity is not necessarily associated with adverse outcomes in patients with COPD. ${ }^{15,17}$ Until the gaps in our understanding of the relationship between obesity, chronic airflow limitation and respiratory symptoms have been filled, the question as to whether it takes two or three to tango remains unanswered...

Conflicts of interest The author declares that he has no conflicts of interest in relation to this article.

Funding None.

Commissioned article; not externally peer-reviewed; accepted 29th April 2012; online 17th May 2012

(c) 2012 Primary Care Respiratory Society UK. All rights reserved http://dx.doi.org/10.4104/pcrj.2012.00040 Prim Care Respir J 2012;21(2):131-3

\section{References}

1. Variations in the prevalence of respiratory symptoms, self-reported asthma attacks, and use of asthma medication in the European Community Respiratory Health Survey (ECRHS). Eur Respir J 1996;9(4):687-95. http://dx.doi.org/10.1183/09031936.96.09040687

2. Voll-Aanerud M, Eagan TM, Plana E, et al. Respiratory symptoms in adults are related to impaired quality of life, regardless of asthma and COPD: results from the European 
community respiratory health survey. Health Qual Life Outcomes 2010;8:107 http://dx.doi.org/10.1186/1477-7525-8-107

3. WHO. Obesity: preventing and managing the global epidemic. Report of a WHO Consultation. WHO Technical Report Series 894. 2000.

4. WHO. Global database on Body Mass Index. [Website]; 2012 [updated 2012; cited]; Available from: http://apps.who.int/bmi/index.jsp.

5. Brown CD, Higgins M, Donato KA, et al. Body mass index and the prevalence of hypertension and dyslipidemia. Obesity research. [Research Support, U.S. Gov't, P.H.S.]. 2000;8(9):605-19.

6. Hubert HB, Feinleib M, McNamara PM, Castelli WP. Obesity as an independent risk factor for cardiovascular disease: a 26-year follow-up of participants in the Framingham Heart Study. Circulation 1983;67(5):968-77. http://dx.doi.org/ 10.1161/01.CIR.67.5.968

7. Salome CM, King GG, Berend N. Physiology of obesity and effects on lung function. J App/ Physiol 2010;108(1):206-11.

http://dx.doi.org/10.1152/ japplphysiol.00694.2009

8. Sin DD, Jones RL, Man SF. Obesity is a risk factor for dyspnea but not for airflow obstruction. Arch Intern Med 2002;162(13):1477-81.

http://dx.doi.org/10.1001/ archinte.162.13.1477

9. Collard P, Wilputte JY, Aubert G, Rodenstein DO, Frans A. The single-breath diffusing capacity for carbon monoxide in obstructive sleep apnea and obesity. Chest 1996;110(5):1189-93. http://dx.doi.org/10.1378/chest.110.5.1189

10. Ofir D, Laveneziana $P$, Webb KA, O'Donnell DE. Ventilatory and perceptual responses to cycle exercise in obese women. J App/ Physiol 2007;102(6):2217-26. http://dx.doi.org/10.1152/japplphysiol.00898.2006

11. Crummy F, Piper AJ, Naughton MT. Obesity and the lung: 2. Obesity and sleep- disordered breathing. Thorax 2008;63(8):738-46

http://dx.doi.org/ 10.1136/thx.2007.086843

12. Beuther DA, Sutherland ER. Overweight, obesity, and incident asthma: a metaanalysis of prospective epidemiologic studies. Am J Respir Crit Care Med 2007;175(7):661-6. http://dx.doi.org/10.1164/rccm.200611-17170C

13. Agusti A, Calverley PM, Celli B, et al. Characterisation of COPD heterogeneity in the ECLIPSE cohort. Respiratory research 2010;11:122.

14. Cecere LM, Littman AJ, Slatore CG, et al. Obesity and COPD: associated symptoms, health-related quality of life, and medication use. COPD 2011;8(4):275-84. http://dx.doi.org/10.3109/15412555.2011.586660

15. Ora J, Laveneziana P, Ofir D, Deesomchok A, Webb KA, O'Donnell DE. Combined Effects of Obesity and COPD on Dyspnea and Exercise Tolerance. Am J Respir Crit Care Med 2009;180:964-71.

16. Ramachandran K, McCusker C, Connors M, Zuwallack R, Lahiri B. The influence of obesity on pulmonary rehabilitation outcomes in patients with COPD. Chron Respir Dis 2008;5(4):205-9. http://dx.doi.org/10.1177/1479972308096711

17. Landbo C, Prescott E, Lange P, Vestbo J, Almdal TP. Prognostic value of nutritional status in chronic obstructive pulmonary disease. Am J Respir Crit Care Med 1999;160(6):1856-61

18. Franssen FM, O'Donnell DE, Goossens GH, Blaak EE, Schols AM. Obesity and the lung: 5. Obesity and COPD. Thorax 2008;63(12):1110-17. http://dx.doi.org/10.1136/thx.2007.086827

19. Zutler M, Singer JP, Omachi TA, et al. Relationship of obesity with respiratory symptoms and decreased functional capacity in adults without established COPD. Prim Care Respir J 2012;21(2):194-201. http://dx.doi.org/10.4104/ pcrj.2012.00028

\section{education@pcrj: the launch of a new initiative for the PCRJ}

\section{*Hilary Pinnock', Jaime Correia de Sousa}

a Senior Clinical Research Fellow, Allergy and Respiratory Research Group, Centre for Population Health Sciences, University of Edinburgh, UK

b Senior Lecturer, Community Health Department, Life and Health Sciences Research Institute (ICVS), School of Health Sciences, University of Minho, Portugal

*Correspondence: Dr Hilary Pinnock, Allergy and Respiratory Research Group, Centre for Population Health Sciences, The University of Edinburgh, Doorway 3, Medical School, Teviot Place, Edinburgh, EH8 9AG, UK

Tel: +44 (0)131650 8102 Fax: +44 (0)131650 9119

E-mails: hilary.pinnock@ed.ac.uk

jaimecsousa@gmail.com

The PCR has two declared aims in the context of primary care respiratory medicine: firstly, to be an 'authoritative setting for the publication of high quality internationally-relevant research'; and secondly, to 'inform and educate healthcare professionals worldwide of the research and service developments' in this field. ${ }^{1}$ This issue sees the launch of a new section in the Journal, education@pcrj, which will significantly promote the second of these two aims. As newly appointed Section Editors, we are delighted to accept the challenge laid down by the Editors-in-Chief, and look forward to delivering this core component of the PCRJ's editorial strategy. Our aim is to "satisfy the needs of "grass roots" primary care clinicians in implementing and applying research findings in practice'. ${ }^{1}$

Pre-empting this launch, journalwatch@pcrj first appeared in the March 2012 issue. ${ }^{2}$ Produced by the Editors-in-Chief, this will be a regular feature of education@pcrj from now on, enabling busy primary care clinicians to keep up-to-date with the latest research evidence from the top respiratory and general medical journals worldwide. Guideline summaries have always been a popular feature of the Journal|3,4 and these will appear in education@pcrj on a regular basis. Similarly, 'Evidence into practice' articles, short review articles of no more than 2000 words in length, will demonstrate how evidence from research can lead to changes in clinical practice.

The PCRJ has previously published Case-based learning ${ }^{5}$ articles similar to the traditional type of Case report, but in the future these will be incorporated into education@pcrj and re-formatted. The section in this issue on the importance of co-morbid rhinitis in patients with asthma demonstrates our new approach. It starts with a short clinical scenario - reflecting where we start as clinicians - and Scadding and Walker then provide a clinical overview of the management of the patient with co-morbid rhinitis and asthma together with an authoritative review of the evidence base. ${ }^{7}$ Exemplifying the fine balance between clinical practicalities and academic theory is the juxtaposition of a table summarising the academic evidence for a link between rhinitis and asthma with a practical illustration of how to use a nasal spray (which should be required reading for every primary care clinician and pharmacist... ). This review is then followed by two Perspectives - a new article category for the PCRJ: Osman Yusuf highlights the issues when 